\title{
Relationship of Diet and Lifestyle with Blood Sugar Levels in the Elderly with Diabetes Mellitus at Internist Room in Dr. Moedjito Dwidjosiswoyo Hospital of Jombang
}

\author{
Dina Aulia ${ }^{1}$, Sentot Imam², \\ Soemarko ${ }^{3}$ \\ ${ }^{1}$ Hospital of Mujito, Jombang, \\ Indonesia \\ ${ }^{2}$ Master Program of Public Health, \\ Institute of Health Sciences Strada \\ Indonesia \\ ${ }^{3}$ Ners Education Study Program, \\ Institute of Health Sciences Strada \\ Indonesia \\ Email: \\ dinaauliapraktek@gmail.com
}

Received : February 16 2021

Accepted : February 16 2021

Published : May 20 2021

\begin{abstract}
The high number of people with diabetes mellitus is due to changes in people's lifestyle, knowledge level, and awareness to do early detection of diabetes mellitus disease that is lacking, lack of physical activity traditional dietary arrangements containing carbohydrates and fiber from vegetables to diet to the west with a composition of foods that have too much protein, fat, salt, and sugar. The purpose of the study was to find out the relationship of diet and lifestyle with blood sugar levels in the elderly with diabetes mellitus. The design of this research is crossectional analytics. The variables of this study are diet and lifestyle as independent variables as well as blood sugar levels as dependent variables. The study population is all elderly diabetes mellitus patients (> 50 years old) and can communicate well in the poly disease in dr. Moerdjito Jombang Hospital as many as 145 patients. Samples were taken with simple random sampling techniques as many as 107 respondents. The data was collected with questionnaire instruments and processed using editing, coding, scoring and tabulating and tested with linear regression tests. The results of this study showed that partially and simultaneously (simultaneously) independent variables can affect the occurrence of dependent variables due to the value of $<0.05$. This indicates that modern lifestyles that often consume fast food or fast food cause an increased risk of DM disease, including consuming beverages containing artificial sweeteners and excessive consumption of carbohydrates that can increase the risk of developing DM disease higher. Unhealthy diet that is by ignoring the type, amount and schedule or frequency of consumption that can cause metabolic disorders in the body, one of which is disorders in glucose metabolism.
\end{abstract}

Keywords: Diet, lifestyle, blood sugar levels, elderly, DM

Copyright $@ 2021$ IIK STRADA Indonesia All right reserved. This is an open-acces article distributed under the terms of the Creative Commons Attribution-ShareAlike 4.0
International License.

\section{INTRODUCTION}

Epidemiological transmission of infectious diseases into non-communicable diseases is increasingly clear, due to changes in people's behavior, such as unhealthy lifestyles, high consumption of junk-food and fast food, high-calorie food consumption, consumption of fatty foods, consumption of cigarettes and alcohol, and low consumption of fiber, fruit and vegetables, and physical activity. It is projected that by 2030, the number of pain caused by non-communicable diseases (PTM) and accidents 
will increase and infectious diseases will decrease (Kemenkes, 2012). One ptm that attracts a lot of attention is Diabetes Mellitus (DM). DM is a health disorder in the form of a collection of symptoms caused by increased blood sugar (glucose) levels due to lack or insulin resistance. DM is a chronic disease that requires ongoing medical treatment. The disease is growing in terms of cases as well as in terms of diagnosis of therapy. Among the wider community, this disease is better known as sugar disease, or diabetes (Silaban, 2012).

Diabetes Mellitus (DM) or sugar or diabetes disease is a disease characterized by blood glucose levels that exceed normal (hyperglycemia) due to the body's lack of insulin, and diseases that occur due to the reduction of insulin both absolute and relative in carbohydrate metabolism. The increasing variety of people's lifestyles is one of the causes of the increase in the number of patients with diabetes mellitus (Hasdianah, 2012).

The International Diabetes Federation (IDF) in 2017 reported that the number of DM patients in the world in 2017 reached 425 million adults aged between 20-79 years. According to Basic Health Research (Riskesdas) data of the Ministry of Health 2018, DKI Jakarta Province occupies the highest prevalence of diabetics, namely 3.4\% (about 250,000 sufferers), followed by DIY (3.1\%), East Java (3.1\%). The prevalence of diabetes patients in East Java province is in the top 10 throughout Indonesia with a prevalence of $6.8 \%$ (Kominfo Jatim, 2015). The results of a preliminary study conducted at the Outpatient Poly Hospital dr. Moedjito Dwidjosiswoyo Jombang found that people with Diabetes Mellitus (DM) in 2018 as many as 366 patients and there was a decrease in 2019 as many as 325 patients and the number of people with Diabetes Mellitus (DM) in March 2020 as many as 122 patients. The results of interviews of $5 \mathrm{dm}$ sufferers in poly diseases in the data obtained entirely stated that they had tried to apply a healthy lifestyle such as reducing or even avoiding sweet foods, trying to exercise regularly according to schedule and ability.

Diabetes mellitus disease is generally caused by the consumption of uncontrolled food or as a side effect of the use of drugs. Diabetes mellitus is caused by insufficient insulin hormone produced by the pancreas to neutralize blood sugar in the body. As a result the pancreas can not produce enough insulin hormone to neutralize blood sugar (Data Center \& Information Ministry of Health RI, 2014). The high number of people with diabetes mellitus is due to changes in people's lifestyle, knowledge level, and awareness to do early detection of diabetes mellitus disease that is lacking, lack of physical activity, traditional dietary arrangements containing carbohydrates and fiber from vegetables to diet to the west with the composition of foods that have too much protein, fat, salt, and sugar (Ministry of Health, 2011). DM disease is widely known to people as a disease closely related to food intake. Excessive intake of foods such as carbohydrates/ sugars, proteins, fats, and energy can be an early risk factor for DM events. The more excessive the food intake, the more likely it will cause DM. Carbohydrates will be digested and absorbed in the form of monosaccharides, especially sugars. The absorption of sugar leads to increased blood sugar levels and encourages increased secretion of the hormone insulin to control blood sugar levels (Linder, 2008).

Lifestyle is a lifestyle of a person in the world expressed in his activities, interests and opinions that describe the whole self of a person who interacts with his environment. Lifestyle can be influenced by several social factors. Social factors that affect food consumption are income level, expenditure, education and knowledge (Tawakali, 2017). People who are at high risk of suffering from DM are those over 45 years old. The prevalence of DM will increase with increasing age, until the old age group Normal blood sugar levels tend to increase gradually after reaching the age of 50 years. To lower blood sugar levels, it is necessary to do physical activities such as exercising, because muscles use glucose contained in the blood as energy (Adib, 2011)

Diabetes Mellitus is a degenerative disease that can be controlled with four pillars of management. Diet is one of the important things in the four pillars of DM management because patients do not pay attention to a balanced food intake. Increased blood sugar in DM patients acts as a cause of an imbalance in the amount of insulin, therefore diet becomes one of the preventions so that blood sugar does not increase, with the right diet can help control blood sugar (Soegondo,2015). Controlling normal blood sugar levels requires proper management of the DM diet. Motivation and support from nutrition 
counselors is also needed. This can be done by means of nutrition education through good dietary planning. Counseling activities are periodically needed in the hope that people with diabetes mellitus are motivated about controlling the recommended 3J diet (Number, Schedule and Type) so that blood sugar levels can be controlled.

Based on this background, researchers are interested to conduct further research on "the relationship of diet and lifestyle with blood sugar levels in the elderly with diabetes mellitus in internist poly in the hospital dr. Moedjito Dwidjosiswoyo Of Jombang".

\section{RESEARCH MATERIALS AND METHODS}

The design of this research is analytics with a crossectional approach. The variables of this study are the application of diet and lifestyle as independent variables as well as blood sugar levels as dependent variables. The study population is all elderly diabetes mellitus patients ( $>50$ years old) and can communicate well in the poly disease in dr. Moerdjito Jombang Hospital as many as 145 patients. Samples were taken with simple random sampling techniques as many as 107 respondents. The data was collected with questionnaire instruments and processed using editing, coding, scoring and tabulating and tested with linear regression tests.

\section{RESULT}

\section{Partial Analysis}

Table 1Partial liner regersi analysis (t test) of the influence of Diet and Lifestyle on blood sugar levels in elderly people with Diabetes Mellitus in Poly Diseases in Dr. Moedjito Dwijosiswodjo Hospital in August 2020 (n=107)

\begin{tabular}{|c|c|c|}
\hline Criteria & $\mathrm{t}$ test Value & $\mathrm{P}$ value \\
\hline Dietary & 4,471 & 0.000 \\
\hline Lifestyle & 5,401 & 0.000 \\
\hline
\end{tabular}

Based on the results in table 1 shows that the $\mathrm{p}$ value of both independent variables (diet and lifestyle) is less than 0.05 so that partially or on its own independent variables (diet and lifestyle) affect the patient's blood sugar levels.

\section{Simultaneous Analysis}

Table 2Simultaneous or simultaneous multivariate analysis of the influence of Diet and Lifestyle on blood sugar levels in elderly people with Diabetes Mellitus in Poly Diseases in Dr. Moedjito Dwijosiswodjo Hospital in August 2020 (n=107)

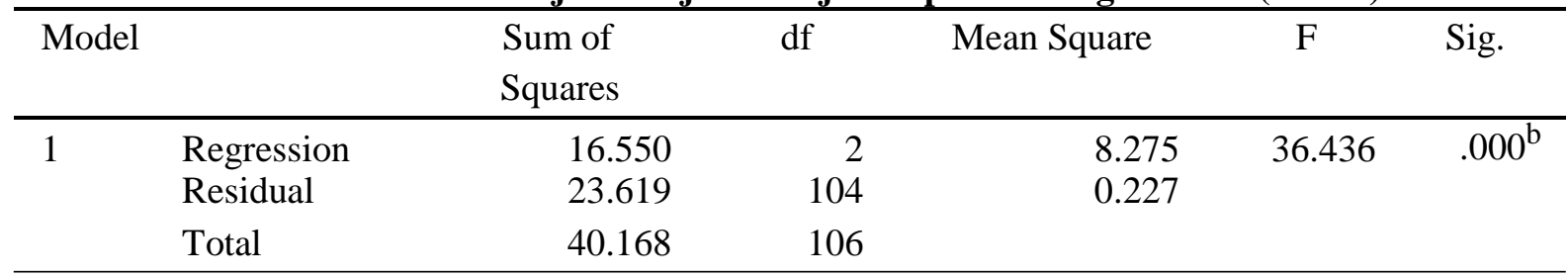

a. Dependent Variable: Blood Sugar Level

b. Predictors: (Constant), Dietary, Lifestyle

Based on the results in table 2 shows that the value of significance shows a value $=0.000$ which means less than 0.05 so that it can be expressed simultaneously or simultaneously independent variables (diet and lifestyle) affecting the blood sugar levels of the patient. 


\section{Determinatin Coefficient Analysis}

Tabele 3Analysis of coefficients determining the influence of Diet and Lifestyle on blood sugar levels in elderly people with Diabetes Mellitus in Poly Diseases in Dr. Moedjito

Dwijosiswodjo Hospital in August 2020 (n=107)

\begin{tabular}{|c|c|c|c|c|c|}
\hline Model & $\mathrm{R}$ & R Square & $\begin{array}{l}\text { Adjusted R } \\
\text { Square }\end{array}$ & $\begin{array}{l}\text { Std. Error of the } \\
\text { Estimate }\end{array}$ & $\begin{array}{l}\text { Durbin- } \\
\text { Watson }\end{array}$ \\
\hline 1 & .642 & .412 & .401 & .477 & 1.874 \\
\hline
\end{tabular}

Table 3 explains that the R Square (R2) value of 0.412 or $41.2 \%$ indicates the contribution of independent variables (diet and lifestyle) while the remaining $58.8 \%$ is influenced by other factors not in this research model. Multiple correlation coefficients are used to measure the density of the relationship between independent and dependent variables. The coefficient of double correlation is indicated by a value (R) of 0.642 or $64.2 \%$ indicating that independent variables (diet and lifestyle) to blood sugar levels in the elderly with diabetes mellitus have a close relationship.

\section{DISCUSSION}

A. Diet of Elderly With Diabetes Mellitus in Internist Poly At Dr. Moedjito Dwijosiswodjo Hospital

Based on the results of the study obtained data most respondents have a healthy diet as many as 67 respondents $(63 \%)$ unhealthy diet as many as 40 respondents (37\%)

The results of this study were supported by Khoiroh research (2019) which showed that the diet of DM type sufferers was mostly good 54 respondents (54.0\%) and not good 36 (36.0\%). Another research that supports this research is Susanti research (2018) which shows that based on dietary variables in Puskesmas Tembok Dukuh Surabaya some of the respondents set their diet quite well with the number of 15 respondents (38\%).

Diet is a style or habit of daily consumption where there are amounts, types and schedules of consumption that are considered. Diet is also an effort to fulfill nutrition by individuals in order to maintain health status (Sulistyoningsih, 2011). A healthy diet is defined as a diet with 3J planning i.e. the amount, type, and regular eating schedule. An unhealthy diet causes a lack of balance between carbohydrates and other content needed by the body. As a result the sugar content in the body becomes high exceeding the working capacity of the pancreas and resulting in the occurrence of diabetes mellitus (Santoso \& Ranti, 2012).

The results of this study showed that some respondents have a healthy diet. This happens because respondents have had enough informais about how to maintain health so that there is no disturbance during the elderly, especially keeping blood sugar levels within the normal range. With this understanding, respondents can realize the importance of maintaining and regulating their diet so that many maintain a healthy diet. While in respondents whose diet in the unhealthy category occurs because the respondent ignores the type, number and schedule or frequency of consumption that can cause metabolic disorders in the body. At a time when health status is declining, nutritional fulfillment is one of the proponents of good healing. According to the researchers, the majority of respondents' diets were good.

Based on data from cross tabulation between the characteristics of respondents and patterns, namely based on the age of respondents obtained data from 14 respondents aged 51-60 years there were 7 respondents $(50 \%)$ who have a healthy diet and 7 respondents (50\%) unhealthy diet. From 36 
Relationship of Diet and Lifestyle with Blood Sugar Levels.....

respondents aged 61-70 years there were 12 respondents (33.3\%) unhealthy diet and 24 respondents $(66.7 \%)$ have a healthy diet. Of the 57 respondents aged $>70$ years old there were 21 respondents (36.8\%) have a healthy diet and 36 respondents (63.2\%) have a healthy diet.

According to notoatmojo (2012), that in someone who is getting older, someone will be better prepared for an event. According to Suhardi (2012), age is a unit of time that measures the time of the existence of an object or living being. According to Sartika (2013) mentions the older the individual, the ability of the tissue is decreasing so that in the collection of blood glucose decreases

Based on this, researchers assume that as a person gets older the less the ability of the respondent's tissue in blood glucose intake so that in the early elderly age is more vulnerable. while the more age, the more needs of nutrient intake needed by the body. So that with the understanding of respondents respondents are increasingly aware of the importance of maintaining their health by regulating the diet in accordance with the information or advice received from health workers.

Based on the education of respondents obtained data from 10 respondents who graduated from elementary school there were 2 respondents (20\%) unhealthy diet and 80 respondents $(80 \%)$ healthy diet, in 22 respondents who graduated from jss there were 7 respondents $(31.8 \%)$ unhealthy diet and 15 respondents $(68.2 \%)$ His diet is unhealthy. Of the 33 respondents who graduated from high school there were 14 respondents $(42.4 \%)$ unhealthy diet and 19 respondents $(57.6 \%)$ unhealthy diet. And out of 42 respondents who graduated from college there were 17 respondents $(40.5 \%)$ unhealthy diet and 25 respondents $(59.5 \%)$ Healthy diet.

Education is a process of adding science through gradual guidance. Similarly, the research results of Shara Kurnia (2012), which in the analysis made 2 categories, namely low and high. It said education is low if respondents do not go to school until the end of junior high school and higher education for high school hongga college. In the analysis obtained results that most respondents are poorly educated. Education is one of the efforts to develop personalities and abilities inside and outside the school and lasts a lifetime. Education affects the learning process, the higher the level of education of a person the easier it is for the person to receive information from either others or the mass media. The more information that comes in the more knowledge gained (Notoatmodjo, 2012). Good methods that can increase awareness of people with diabetes mellitus to make a better diet and lifestyle is emberian education about the knowledge and understanding of diabetes mellitus disease so as to improve BMI, blood pressure and even sugar levels in the blood (Jinlin \& Terry, 2015).

According to the researchers, the higher the level of education of respondents, the easier it will be to understand the information received, especially about maintaining a healthy diet, so that respondents can maintain health in old age better. The provision of education should be very helpful for patients in carrying out disease control. Based on this, researchers assume that the education that has been taken by a person certainly supports one's ability to manage information well. A person with a higher level of education has knowledge and awareness of health and behaves in a better life.

\section{B. Lifestyle of Elderly With Diabetes Mellitus in Internist Poly At Dr. Moedjito Dwijosiswodjo Hospital}

Lifestyle characteristics of respondents showed that most implemented a healthy lifestyle as many as 65 respondents (61\%) unhealthy lifestyles of 42 respondents (39\%).

The results of this study were supported by research from ALfiani (2017) which showed that almost half of respondents had a good lifestyle of 14 people (47\%).

Lifestyle is defined as a way of life identified by how a person spends their time (activities), what they consider important in their environment (interests), and what they think of themselves and the world around them (Setiadi, 2010). Lifestyle is very influential on a person's physical and psychic condition. Lifestyle changes and low healthy lifestyle behaviors can cause a variety of health problems. A healthy lifestyle includes a multidimensional structure. Lifestyle affects the form of behavior or habits of a person in response to physical and psychic health, environment, social, cultural and economic (Khasanah, 2012). 
The results of this study that most respondents have a healthy lifestyle include reducing the consumption of fatty and sweet foods, reducing alcohol consumption and reducing the number of cigarettes smoked and exercising regularly every day. This happens because respondents feel that they should be able to maintain or diodify the respondent's lifestyle into a healthy lifestyle in old age so that respondents can maintain their health well, especially in maintaining their blood sugar levels. While in respondents who have an unhealthy lifestyle such as still consuming a lot of sweet foods, sports activities are lacking so that it affects their blood sugar levels. In addition, because of the busyness of respondents in work or also because of the influence of technological developments so that respondents rarely to do regular exercise such as morning running, cycling, or also morning walk, in addition respondents rarely control blood sugar levels so that respondents are late knowing their blood sugar levels are increasing.

Based on education respondents obtained data from 10 respondents who graduated from elementary school mostly have a healthy lifestyle as many as 8 respondents (80\%) and of the 22 respondents who graduated from junior high school, most had a healthy lifestyle as many as 16 respondents $(72.7 \%)$. Of the 33 respondents who graduated from high school, the data showed that most had a healthy lifestyle as many as 17 respondents $(51.5 \%)$ and of the 42 respondents who graduated from college, most also had a healthy lifestyle as many as 24 respondents $(57.1 \%)$.

According to Mubarak (2013) educational background can affect a person's knowledge where education means the guidance one provides to others on something so that they can understand. It is undeniable that the higher a person's education the easier it is for them to receive information, and ultimately the more knowledge they have. Conversely, if a person has a low level of education, it will hinder the development of one's attitude towards the acceptance of newly introduced information and values.

According to educational researchers greatly influence a person in obtaining information. Respondents' educational background is higher education. Although respondents have a higher education if respondents do not try to change their behavior in carrying out daily activities, such as rarely exercising, still often consume sweet foods, when in fact respondents know it is unhealthy, but respondents still do these activities so that the lifestyle of diabetics can be said to be unhealthy lifestyle. Higher education but not supported by a strong desire to change healthy lifestyles, respondents will still live an unhealthy lifestyle.

Based on the work of respondents obtained data from 10 respondents who did not work most have a healthy lifestyle as many as 8 respondents $(80 \%)$. Of the 41 respondents who worked as private employees, most had a healthy lifestyle as many as 25 respondents (61\%). Of the 14 respondents who worked self-employed, most had a healthy lifestyle as many as 8 respondents $(57.1 \% 0$ and of the 42 respondents who worked as civil servants, most had a healthy lifestyle as many as 24 respondents $(57.1 \%)$.

Based on respondents' information sources obtained data from 44 respondents who obtained information from health workers mostly have a healthy lifestyle as many as 27 respondents $(61,450$ Out of 41 respondents who obtained health information from families showed most had a healthy lifestyle as many as 24 respondents $(58.5 \%)$. And of the 22 respondents who obtained information from print and electronic media, most also had a healthy lifestyle as many as 14 respondents (63.6\%).

According to Erfandi (2011) stated that as a means of communication, various forms of mass media such as television, radio, newspapers, magazines, and others have a great influence on the formation of opinions and beliefs of people. In the delivery of information as the main task, the mass media carries a pattern of messages containing suggestions that can direct one's opinion.

The results of this study showed that many respondents who obtained information from health workers so that they can apply the information in meeting their daily needs and resonden lifestyle can be healthier, but in respondents who get information from the mass media or from magazines that are commonly read so that the information is still incomplete. The information obtained from the magazine is only used as reading material, but most respondents read magazines but are not applied in everyday life so many have not been able to apply such behavior properly. 


\section{Blodd Sugar Level Eldery With Diabetes Mellitus in Internist Poly At Dr. Moedjito Dwijosiswodjo Hospital}

Characteristics of blood sugar levels of patients showed that most respondents had blood sugar levels in the normal category as many as 65 respondents $(61 \%)$, high blood sugar levels as many as 28 respondents (2650 and low blood sugar levels as many as 14 respondents (13\%).

The results of this study are in accordance with Susanti's research (2018) which showed that respondents' blood sugar levels were classified as hyperglycemia blood sugar levels of 18 respondents $(45 \%)$.

. Diabetes Mellitus (DM) is a metabolic disease (mostly hereditary) as a result of a lack of effective insulin either due to the dysfunction of pancreatic beta cells or glucose intake in peripheral tissues, or both (DM-Type 2), or the lack of absolute insulin (DM Type1), with signs of hyperglycemia and glucouria, accompanied by acute clinical symptoms (polyuria, polydipsia, weight loss), and or chronic or sometimes symptomatic symptoms. The primary disorder lies in carbohydrate metabolism, and secondary to the metabolism of fats and proteins (Tjokroprawiro, 2010).

Increased blood sugar levels in people with diabetes mellitus will put the individual in a dangerous condition, because the effects of increasing sugar levels can be fatal for people with Diabetes Mellitus. Therefore, in every person with diabetes mellitus is required to be vigilant and always supervise or control the condition of blood sugar levels in order to avoid complications of diabetes mellitus.

Based on the results of cross tabulation between the characteristics of respondents and variable blood sugar levels. Based on the age of respondents obtained data from 14 respondents aged 51-60 years, most had blood sugar levels in the normal range of 9 respondents (64.3\%). Of the 36 respondents aged 61-70 years, most had blood sugar levels in the normal range of 22 respondents and from 57 respondents aged $>70$ years most had sugar levels in the normal category of 34 respondents $(59.6 \%)$

Type II Diabetes Mellitus (DM) is most common in people with Diabetes Mellitus who are over 30 years old and obese. Due to the slow (for years) and progressive glucose intolerance, type II Diabetes Mellitus can run undetected. If the patient has symptoms, they are often mild and can include fatigue, irritability, polyuria, polydipsia, long-healed skin wounds, vaginal infections or blurred vision (if glucose levels are very high). Nowadays there is a tendency in urban communities to suffer more from diabetes mellitus than rural communities. This is associated with changes in the lifestyle of urban people associated with diabetes risks such as obesity, lack of physical activity, and unhealthy lifestyles such as alcohol consumption. Various studies have shown that alcohol consumption can lower the risk of diabetes mellitus. Alcohol inhibits the liver from releasing glucose to the blood so that blood glucose levels can drop. Consumption of alcohol, diabetes drugs and insulin injections can lead to hypoglycemia. In very rare cases, alcohol can increase blood glucose because it contains high calories (Tjandra, 2012)

The results showed that most respondents were over 40 years old or most respondents were elderly. This indicates that increasing age will affect the decrease of fungi of the body organs, one of which is the function of the pancreas in producing insulin so that there is an increase in blood sugar levels. If the sugar levels in the blood can not be controlled and become high because glucose is difficult to enter the cells. High sugar levels are caused by the body producing little or no insulin at all. This disease causes weight loss and endurance so that the patient's body becomes weak and easily feel hungry.

D. The relationship between diet and blood sugar levels of diabetic mellitus in Internist Poly At Dr. Moedjito Dwijosiswodjo Hospital 
Relationship of Diet and Lifestyle with Blood Sugar Levels.....

Based on the results showed that most respondents who have an unhealthy diet blood sugar levels in the high category as much as 22 respondents (55\%). In respondents who have a healthy diet most blood sugar levels in the normal category as many as 48 respondents $(71.6 \%)$

Based on the results in table 1 shows that the $\mathrm{p}$ value of both independent variables (diet and lifestyle) is less than 0.05 so that partially or on its own independent variables (diet and lifestyle) affect the patient's blood sugar levels.

Diabetes mellitus (DM) is known by the public as diabetes or chronic disease that is characterized by an increase in blood sugar levels as a result of the presence of metabolic system disorders in the body. This can be caused by the failure of pancreatic organs to produce the hormone insulin as needed. Diets that tend to keep the concept of eating balanced can have a negative impact on health and nutrition. Food consumption patterns that can lead to diabetes mellitus is the pattern of consumption of foods containing excess amounts of calories, high in saturated fats and sugars, low in fiber and low in micronutrients will cause obesity problems, more nutrition, as well as increase free radicals that eventually lead to changes in disease patterns, from infection to non-infectious chronic diseases or trigger the emergence of degenerative diseases (Suiraoka, 2012). DM sufferers are still allowed to eat like normal people but must be able to control it both in terms of meal schedule, amount, and type of food consumed (Sudarmingsih, 2012).

A good diet should be understood by people with DM in the setting of daily diet. This pattern includes setting a schedule for DM sufferers which is usually 6 meals per day which is divided into 3 large meals and 3 inters/ meals. Dietary regulation is the main basis for controlling Diabetes Mellitus. The most important thing is to pay attention to the content of glucose and foods that contain many sources of carbohydrates contained in these foods. Diet should be done regularly, namely morning, afternoon and afternoon and snacks between meals. DM patients who should pay more attention to the food schedule, type and amount of food intake so as not to experience hypoglycemia (Decreased blood sugar levels of less than $60 \mathrm{mg} / \mathrm{dl}$ ) which is dangerous for sufferers.

\section{E. The relationship between lifestyle and blood sugar levels of Diabetic Mellitus in Internist Poly At Dr. Moedjito Dwijosiswodjo Hospital}

Based on the lifestyle of respondents showed that the majority of respondents who have an unhealthy lifestyle blood sugar levels in the high category as many as 26 respondents $(61.9 \%)$ and in respondents who have a healthy lifestyle most of their blood sugar levels in the normal category as many as 52 respondents $(11 \%)$

Based on the results in table 1 shows that the $\mathrm{p}$ value of both independent variables (diet and lifestyle) is less than 0.05 so that partially or on its own independent variables (diet and lifestyle) affect the patient's blood sugar levels.

The results of this study were supported by Rohmah research (2017) which examined the dilihart lifestyle of respondents' activity habits obtained data from a number of 56 respondents there were 49 respondents with light physical activity had uncontrolled blood sugar levels of 36 people $(73.50 \%)$ and 13 people $(26.50 \%)$ with blood sugar levels under control. While 7 people with heavy activities have uncontrolled blood sugar levels as much as 2 people $(28.6 \%)$ and $5(71.4 \%)$ people with controlled blood sugar levels.

According to Beavers (2012) states lifestyle factors can affect blood sugar levels and cause diabetes mellitus disease namely, alcohol, caffeine, potassium and calcium (fruits and vegetables) and exercise or physical activity. Then Cahyono (2012) stated that due to many wrong or unhealthy living habits such as smoking, alcoholism, stomach obesity, junk food (fast food) can cause degeneratives such as, coronary heart disease, stroke and hypertension. To overcome the problem, public awareness is needed or People with Diabetes Mellitus control their blood sugar levels within normal limits through trying to live a healthy life so as to avoid the threat of degenerative diseases (Dalimartha et al, 2011).

Lifestyle in modern society today is very vulnerable to health problems, one of which is degenerative diseases such as diabetes mellitus. It does not close the possibility of lifestyle factors 
(such as consuming foods that are harmful to health, abusing alcohol, meorok, psychological and occupational stress, lack of movement or exercise) can affect the behavior of people with Diabetes Mellitus in maintaining their health, so that it will have an impact on the condition of blood sugar levels of Diabetic Mellitus. For now curative treatment is not enough to cure or keep blood sugar levels of Diabetic Mellitus low. Various factors that can increase blood sugar levels, only lifestyle factors can be changed and can be used as an alternative to non-medical therapy.

Based on the results of the study can be seen that People with Diabetes Mellitus whose healthy lifestyle mostly shows normal blood sugar levels while People with Diabetes Mellitus with unhealthy lifestyle category most of their blood sugar levels have increased or uncontrolled. This condition indicates with a healthy and good lifestyle, blood sugar levels will be decreasing or controlled so as to minimize the occurrence of complications of blood sugar levels such as gangrene wounds and death netting the brain and even death. A healthy lifestyle that is the responsibility of health, adequate physical activity, balanced nutrition as needed, not smoking, not abusing drugs and can management srtes, is a non-pharmacological therapy that can be lived by every Diabetic Mellitus safely without causing side effects to health. this is important because it can improve the degree of health and in particular can control blood sugar levels in preventing complications of diabetes mellitus. In patients with unhealthy lifestyles there are respondents who have normal blood sugar levels and hypoglycemia. This happens because in respondents who have a healthy lifestyle in case they rarely exercise and also they have a busy work, but the respondents still try to consume nutritious and healthy foods, in addition they are also disobedient in taking drugs.

\section{F. The relationship between Dietary and lifestyle with blood sugar levels of Diabetic Mellitus in Internist Poly At Dr. Moedjito Dwijosiswodjo Hospital}

Based on the results in the table shows that the value of significance shows a value $=0.000$ which means less than 0.05 so that it can be expressed simultaneously or simultaneously independent variables (diet and lifestyle) affecting the blood sugar levels of the patient

Table 3 explains that the R Square (R2) value of 0.412 or $41.2 \%$ indicates the contribution of independent variables (diet and lifestyle) while the remaining $58.8 \%$ is influenced by other factors not in this research model. Multiple correlation coefficients are used to measure the density of the relationship between independent and dependent variables. The coefficient of double correlation is indicated by a value $(\mathrm{R})$ of 0.642 or $64.2 \%$ indicating that independent variables (diet and lifestyle) to blood sugar levels in the elderly with diabetes mellitus have a close relationship.

According to Bela (2018) Education of a good diet and followed by physical activity or gymnastics can help the absorption of DM obtained from education or counseling on diet and physical activity. Raga (2016) stated that nutrition education can change the understanding of individual groups, and society in the field of health as something valuable, independent, in achieving healthy living goals, and can use existing health care facilities appropriately and appropriately or in general to change public health behaviors. According to Farrell (2018), modern lifestyles that often consume fast food or fast food cause an increased risk of DM disease, including consuming beverages containing artificial sweeteners and excessive consumption of carbohydrates that can increase the risk of $7 \%$ higher. Unhealthy diet is by ignoring the type, amount and schedule or frequency of consumption that can cause metabolic disorders in the body. At a time when health status is declining, nutritional fulfillment is one of the proponents of good healing.

The results of this study showed that with a good diet and a healthy lifestyle such as doing exercise regularly, a lot of activities will help the elderly who have diabetes mellitus in maintaining and maintaining the blood sugar levels of respondents within the norm rangel.

\section{CONCLUTION}

1. The diet of elderly people with diabetes mellitus in internist Poly At Dr. Moedjito Dwijosiswodjo Hospital mostly shows a healthy diet 
2. The lifestyle of elderly people with diabetes mellitus in internist Poly At Dr. Moedjito Dwijosiswodjo Hospital Hospital mostly indicates a healthy lifestyle.

3. Blood sugar levels of elderly people with diabetes mellitus in internist Poly At Dr. Moedjito

Dwijosiswodjo Hospital are mostly within the range of normal blood sugar levels.

4. There is a relationship between diet and blood sugar levels in the elderly with diabetes mellitus in internist Poly At Dr. Moedjito Dwijosiswodjo Hospital

5. There is a relationship between lifestyle and blood sugar levels in the elderly with diabetes mellitus in internist Poly At Dr. Moedjito Dwijosiswodjo Hospital

\section{SUGGESTED}

1. For Health Officer

It is expected that health workers, especially the nursing profession can encourage or provide health education in response to the problem of Diabetes Mellitus in controlling blood sugar levels through healthy diet and lifestyle so as to improve the effectiveness of health services for people with Diabetes Mellitus educationally, promotively, and rehabilitatively.

\section{For Respondent And Family}

It is expected that the results of this study can be practiced in daily life in providing support, motivation and can be used as a reference for non-medical therapy information through maintaining a healthy diet and lifestyle modification during the treatment process.

\section{For Place Of Research}

To the institution is expected from the results of this research can be disseminated to people with Diabetes Mellitus and family, so that with additional information will be able to understand about the modification of a healthy lifestyle and a healthy diet in the maintenance of health.

\section{For Next Researcher}

It is expected that researchers can further conduct research by examining other factors that can affect lifestyle or blood sugar levels in people with Diabetes Mellitus such as researching the relationship of obesity and education with blood sugar levels, so that it can play a role in the development of science and technology in the world of nursing.

\section{ACKNOWLEDGMENTS}

The author would like thank to Allah SWT, to my husband, children, parents, and my beloved sister who have provided good moral and material support so far so that I was able to complete this thesis. Furthermore, thanks and highest appreciation to this thesis supervisor Dr.dr.Sentot Imam S,M.M, who provided guidance, corrections, and suggestions for the realization of this thesis. And also for Prof. Dr. Sandu Siyoto, S.Sos., S.KM., M.Kes as the rector of IIK STRADA Indonesia Kediri, the lecturers who examined the proposal and thesis, all lecturers and staff of IIK STRADA Indonesia Kediri, head and all staff of internist Poly At Dr. Moedjito Dwijosiswodjo Hospital, friends of IIK STRADA Indonesia Kediri students, and all parties who have helped the smooth writing of this thesis which cannot be mentioned one by one

\section{REFERENCE}

Arisman, 2011. Perawatan Pasien Diabet. Jakarta: Penerbit Buku Kedokteran EGC.

Basuki. 2015. Pengobatan Diabet. Edisi kedua. Sagung Seto: Jakarta

Black, M. Joice \& Jane Hokanson Hawks. 2014. Keperawatan Medikal Bedah, Edisi 8. Buku 2. Elseiver INC All Right Reserved. American Bulechek.

Donsu, Jenita Doli Tine. 2016. Metodologi Penelitian. Yogyakarta : Pustaka Baru Press

Ghozali, Imam. 2011. Aplikasi Analisis Multivariate. Badan Penerbit Universitas Diponegoro. Semarang International Diabetes Federation. 2017. International Diabetes Federation Diabetes Atlas 7th edition Kemenkes RI. 2011. Informasi Pengendalian penyakit dan pencegahan Diabetes Mellitus. Jakarta : Ditjen PPM Dan PL DepKes RI 
Kementerian Kesehatan. 2012. Petujuk Teknis Pengaruh Faktor Risiko Diabetes Mellitus, Penyakit Metabolik. Jakarta : Direktorat PPTM Ditjend PP\&PL.

Linder. 2008. Bebas Diabetes Tipe-2 Tanpa Obat. Jakarta: AgroMedia Pustaka

Nita G Forouhi professor. 2018. Dietary and nutritional approaches for prevention and management of type 2 diabetes. BM Journal 2018;361:k2234

Nursalam. 2013. Konsep dan Penerapan Metodologi Penelitian Ilmu Keperawatan. Jakarta : Salemba Medika

Perkumpulan Endokrinologi Indonesia (PERKENI). 2011. Konsensus Pengendalian dan Pencegahan Diabetes Mellitus Tipe2 di Indonesia 2011. Jakarta.

Ravat, 2010. Petunjuk Praktis Pengelolaan Diabetes Tipe II. Jakarta: PERKENI

Senadheera Pathirannehelage. 2016. Dietary Habits of Type 2 Diabetes Patients: Variety and Frequency of Food Intake. Journal of Nutrition and Metabolism Volume 2016

Silaban, 2012. Penatalaksanaan Diabetes Melitus Terpadu. Panduan Penatalaksanaan Diabetes Melitus Bagi Dokter Dan Edukator. Jakarta: Balai Penerbitan FKUI.

Smeltzer, S. C., \& Bare, B. G. 2013. Buku Ajar Keperawatan Medikal Bedah. Jakarta: EGC.

Sugiyono. 2015. Metode Penelitian Kuantitatif, Kualitatif Dan $R \&$ D. Cetakan ke-24. Bandung : Alfabeta.

Susanti. 2018. Hubungan Pola Makan Dengan Kadar Gula Darah Pada Penderita Diabetes Mellitus Jurnal Kesehatan Vokasional Vol. 3 No 1 - Mei 2018

Tawakali. 2017. Hubungan Pengetahuan Diabetes Mellitus Dengan Gaya Hidup Pasien DM Rs Malang. Jurnal Nursing News. Vol 2. No. 2. 2017

Tjokroprawiro. A. 2012. Garis Besar Pola Makan dan Pola Hidup Sebagai Pendukung Terapi Diabetes Mellitus. Surabaya : Fakultas Kedokteran 